\title{
Effect of Moringa oleifera stem extract on hydrogen peroxide-induced opacity of cultured mouse lens
}

\author{
Lei Qi ${ }^{1}$, Yu Zhou ${ }^{2 *}$, Weijie Li ${ }^{2}$, Mali Zheng ${ }^{1}$, Ruisheng Zhong ${ }^{1}$, Xin Jin² and Yuan Lin ${ }^{1}$
}

\begin{abstract}
Background: Moringa oleifera, also known as horseradish tree or drumstick tree, has strong antioxidant properties. In the present study, we investigated the potential effect of Moringa oleifera stem extract (MOSE) on cataract formation induced by oxidative stress in cultured mouse lenses.

Methods: Mouse lenses cultured in vitro were pretreated with MOSE (0.5 and $1 \mathrm{mg} / \mathrm{mL})$ for $24 \mathrm{~h}$. Then, $1 \mathrm{mM}$ hydrogen peroxide was added, and mouse lenses were cultured for a further $24 \mathrm{~h}$. The medium was then changed to normal culture medium. After $48 \mathrm{~h}$, lens opacification, reactive oxygen species (ROS) generation, reduced glutathione (GSH) content, and activities of superoxide dismutase (SOD) and catalase (CAT) were measured in lens tissues. In addition, the protein expression of peroxisome proliferator-activated receptor alpha (PPARa), a nuclear receptor with potential benefits to improve vision-threatening eye diseases, was assayed.
\end{abstract}

Results: MOSE (1 mg/mL) alleviated lens opacification, reduced ROS generation, increased GSH content, and elevated SOD and CAT activities in cultured lenses. Moreover, MOSE upregulated the expressions of SOD, CAT, and PPARa.

Conclusions: This study showed that MOSE alleviates oxidative stress-induced cataract formation, and the mechanism of the effect is mainly related to its improvement of the endogenous antioxidant system in the lens.

Keywords: Moringa oleifera, Lens, Organ culture, Oxidative stress, Antioxidant

\section{Background}

The lens has a transparent, elastic avascular refractive organization and plays an important role in visual formation. Cataracts are characterized by gradual accumulation of cloudy deposits on the ocular lens and have been a leading cause of visual impairment and blindness worldwide for centuries. Although modern cataract surgery is safe and effective, there are still many problems, such as high costs, loss of normal functions of postoperative eyes, and a high incidence of after-cataract. As the aging population increases, cataracts have become an increasingly serious issue $[1,2]$. Thus, there is a great demand for safe, effective, and inexpensive agents to prevent or delay the onset of cataracts.

\footnotetext{
* Correspondence: zhouyu@xmu.edu.cn

${ }^{2}$ Department of Basic Medical Science, School of Medicine, Xiamen

University, Xiamen 361102, People's Republic of China

Full list of author information is available at the end of the article
}

Cataracts are multifactorial eye diseases associated with several risk factors such as aging, diabetes, exposure to sunlight, and hypertension. However, oxidative stress caused by reactive oxygen species (ROS) has long been regarded as the major mechanism by which cells are damaged and cataracts are formed [3-6]. Under physiological conditions, lenses can compensate for a mild degree of oxidant stress and remove oxidative damaged molecules by elevating endogenous antioxidants such as reduced glutathione (GSH) and activating antioxidant enzymes, such as superoxide dismutase (SOD) and catalase (CAT), which play important roles in protecting the lens against oxidative stress. However, in some cases such as aging, ROS production is excessive or the ability of the lens to scavenge ROS decreases, and oxidative stress injuries may occur and then cataracts are formed $[3,4]$.

(c) The Author(s). 2019 Open Access This article is distributed under the terms of the Creative Commons Attribution 4.0 International License (http://creativecommons.org/licenses/by/4.0/), which permits unrestricted use, distribution, and reproduction in any medium, provided you give appropriate credit to the original author(s) and the source, provide a link to the Creative Commons license, and indicate if changes were made. The Creative Commons Public Domain Dedication waiver (http://creativecommons.org/publicdomain/zero/1.0/) applies to the data made available in this article, unless otherwise stated. 
Because of the major role of oxidative stress in cataract formation, natural antioxidants with high activity and few side effects have attracted increasing attention to delay the onset or progression of cataracts [7-10]. Moringa oleifera, also known as horseradish tree or drumstick tree, belongs to the Moringaceae family and has been used in nutritious foods and traditional medicines for the treatment of various diseases such as rheumatism, inflammation, and diabetes in many Asian countries [11]. Particularly, Moringa oleifera is one of the best known and most widely distributed species that is rich in natural antioxidants [12, 13]. Moringa oleifera leaf extracts was reported to inhibit the ROS formation induced by $\mathrm{H}_{2} \mathrm{O}_{2}$ and enhanced the activities and mRNA expressions of SOD and CAT in KB cells [14] and in HEK-293 Cells [15]. Recently the Moringa oleifera leaf extract was reported to protect yeast cells against oxidative stress induced by cadmium and $\mathrm{H}_{2} \mathrm{O}_{2}$ through the reduction of intracellular ROS levels [16]. Regular intake of Moringa oleifera leaves through diet decreased the lipid per oxidation and increase the SOD and CAT activities in a diabetes-induced oxidative stress model in rats [17]. Moringa oleifera seed extract can inhibit the ROS formation induced by high fat diet in mice [18]. Moringa oleifera root extract attenuated beryllium-induced oxidative stress in rats [19]. All these significant antioxidant activities of Moringa oleifera from both in vitro as well as in vivo studies suggest that Moringa oliefera may inhibit the cataract formation induced by oxidative stress. Although some studies have reported that the Moringa oleifera leaf extract has potential inhibitory effects on high sugar-induced cataract in goat lens in vitro [20] and selenite-induced cataract in rat pups [21], no study have actually been conducted on the protective effects of Moringa oleifera on oxidative stress induced cataract. In addition, compared with the traditional uses of the leaves, flowers, and seeds of Moringa oleifera, its stem is not often consumed, and the stem may even be considered as an agricultural by-product. However, Moringa oleifera stem is very abundant and inexpensive. Thus, any health benefit from it may reach a large part of the population. Therefore, it is worthwhile to investigate the potential effects of Moringa oleifera stem on delaying the onset or progression of cataracts induced by oxidative stress. In addition, PPARs (including three isoforms: $\alpha, \gamma$, and $\beta / \delta)$ are ligand-activated transcription factors of the nuclear hormone receptor and play key roles in maintaining glucose and lipid homeostasis by modulating gene expression. Recent studies indicate that PPARs have potential benefits to improve or prevent various vision-threatening eye diseases such as diabetic retinopathy, glaucoma, and diabetic macular edema [22-24]. Therefore, in this research, we also evaluate the effect of Moringa oleifera stem on the expression of PPARs.
Lens organ cultures provide a simple and effective platform to screen for candidate compounds that protect against cataract formation $[25,26]$. Hydrogen peroxide $\left(\mathrm{H}_{2} \mathrm{O}_{2}\right)$ is the main intracellular $\mathrm{ROS}$ in the aqueous humor, which causes cataract development [27, 28], and is often used to induce cataract formation in vitro [8]. Therefore, in the present study, we focused on the protective effect of Moringa oleifera stem extract (MOSE) against cataract formation and explored its underlying mechanism using a cataract formation model induced by $\mathrm{H}_{2} \mathrm{O}_{2}$ in lens organ culture. Luteolin is a flavonoid present in the leaves and stems of many plants and some reports indicate that luteolin exerts protective effects on selenite [29, 30] and STZ [31]-induced cataracts. So luteolin was used as a reference for its established antioxidant property in our research.

\section{Methods \\ Animals}

Experiments were performed using male BALB/c mice weighing 20-22 g (Certificate No. SCXK 2012-0002; Shanghai SLAC Laboratory Animal Co. Ltd., Shanghai, China). Mice were housed under a controlled temperature $\left(22 \pm 1{ }^{\circ} \mathrm{C}\right)$ with a $12 \mathrm{~h}$ light/dark cycle, and allowed free access to food and water. All experimental protocols described in the present study were approved by the Animal Care and Use Committee of Xiamen University (LACUC: XMULAC20150077). All procedures for the animal study were conducted in accordance with ARRIVE guidelines, and every effort was made to alleviate the suffering of the animals.

\section{Reagents}

Medium 199 (M-199), fetal bovine serum (FBS), and an antibiotic solution were purchased from Gibco (Grand Island, NY, USA). 2,2-Diphenyl-1-1-picrylhydrazyl (DPPH), rutin, and luteolin were purchased from SigmaAldrich (St. Louis, MO, USA). 2', 7'-Dichlorofluorescein diacetate (DCFH-DA) and radioimmunoprecipitation assay (RIPA) lysis buffer were purchased from Solarbio (Beijing, China). Other materials used are specified in detail in the following sections.

\section{Preparation of MOSE}

Dry Moringa oleifera stems were purchased from Xiamen Jinzhu Ecological Agriculture Co. Ltd. (Xiamen, Fujian, China). Plant identification was done by Dr. Chenqin, an expert from the School of Pharmaceutical Science of the Xiamen University (Xiamen, China). The voucher specimen (No. 20140002) was kept at the Key Laboratory of Chiral Drugs, Medical College, Xiamen University, Xiamen, China. The dry Moringa oleifera stems were then powdered and extracted with $70 \%$ ethanol at $85^{\circ} \mathrm{C}$ for $2 \mathrm{~h}$. Then, the supernatant was filtered 
using Whatman filter paper and vacuum evaporated to obtain the ethanol MOSE. The extracts were freeze dried into powder form for storage. For experimental use, the freeze-dried powder of MOSE was freshly diluted with M-199 and then filtered through a $0.22 \mu \mathrm{M}$ microfiltration membrane.

\section{Determination of the total flavonoid content in MOSE}

The total flavonoid content in MOSE was measured using a $\mathrm{NaNO}_{2}-\mathrm{Al}\left(\mathrm{NO}_{3}\right)_{3}-\mathrm{NaOH}$ colorimetric assay [32]. Briefly, $10 \mathrm{~mL}$ MOSE solution $(0.1 \mathrm{mg} / \mathrm{mL}$, diluted with $100 \%$ ethanol) was mixed with $1 \mathrm{~mL}$ of $5 \% \mathrm{NaNO}_{2}$, and then $1 \mathrm{~mL}$ of $10 \% \mathrm{Al}\left(\mathrm{NO}_{3}\right)_{3}$ was added. After $5 \mathrm{~min}$, $5 \mathrm{~mL}$ of $1 \mathrm{M} \mathrm{NaOH}$ was added to the mixture. The volume was increased to $25 \mathrm{~mL}$ with $60 \%$ ethanol, and the mixture was allowed to rest for $15 \mathrm{~min}$. Absorbance was measured at $510 \mathrm{~nm}$. All determinations were performed in triplicate. The total flavonoid content was expressed as $\mathrm{mg}$ of rutin equivalents per $\mathrm{g}$ of dried MOSE.

\section{Assay of the DPPH radical scavenging capacity}

The effects of MOSE and luteolin on DPPH scavenging were measured according to a previously reported method [33]. A DPPH radical solution was prepared by dissolving $2 \mathrm{mg}$ DPPH in $50 \mathrm{~mL}$ of $70 \% \mathrm{EtOH}$. MOSE or luteolin was also dissolved in $70 \% \mathrm{EtOH}$ at various concentrations. The DPPH radical solution $(225 \mu \mathrm{L})$ was mixed with $75 \mu \mathrm{L}$ of each sample in a 96-well microplate. An equal volume of EtOH was added to the control well. Absorbance at $517 \mathrm{~nm}$ was measured after 30 min of reaction at room temperature in the dark using a microplate reader. Lower absorbance of the reaction mixture indicated a higher DPPH free radical scavenging activity. The percentage of DPPH radical inhibition was calculated as follows:

DPPH radical inhibition $(\%)=100 \% \times[(\mathrm{A}-\mathrm{B}) / \mathrm{A}]$.

Where $\mathrm{A}$ is the absorbance value of the control reaction (containing DPPH solution only) and B is the absorbance value of the test reaction (containing the DPPH solution and sample). The antioxidant activity of the compound was expressed as $\mathrm{IC}_{50}$ and is defined as the concentration $(\mathrm{lg} / \mathrm{mL})$ of compound that inhibited the formation of DPPH radicals by $50 \%$.

\section{Lens organ culture}

The lens organ culture was prepared according to previous reports with some modifications [25, 34, 35]. First, mice were brought to the carbon dioxide $\left(\mathrm{CO}_{2}\right)$ euthanasia apparatus and then exposed to $\mathrm{CO}_{2}$ until complete cessation of breathing was observed. The mice were then be decapitated and the lenses were isolated through the posterior approach from the eyes and transferred to 6-well plates containing $4 \mathrm{~mL}$ M-199 medium with $1 \%$ penicillin-streptomycin and $2 \%$ FBS per well. Then, the lenses were incubated at $37^{\circ} \mathrm{C}$ in a $5 \% \mathrm{CO}_{2}$ incubator. After $24 \mathrm{~h}$, each lens was observed under an anatomical microscope (Leica S6D; Leica Microsystems, Wetzlar, Germany), and transparent lenses were selected for further experiments. The selected lenses were divided into the following groups: normal control group (lenses cultured in normal medium without $\mathrm{H}_{2} \mathrm{O}_{2}$ exposure); MOSE-treated control group (lenses cultured in medium with $1 \mathrm{mg} / \mathrm{mL}$ MOSE without $\mathrm{H}_{2} \mathrm{O}_{2}$ exposure); vehicle control group (lenses cultured in normal medium before $\mathrm{H}_{2} \mathrm{O}_{2}$ exposure); MOSE (0.5 mg/mL)-treated group (lenses cultured in medium with $0.5 \mathrm{mg} / \mathrm{mL}$ MOSE before $\mathrm{H}_{2} \mathrm{O}_{2}$ exposure); MOSE $(1 \mathrm{mg} / \mathrm{mL})$-treated group (lenses cultured in medium with $1 \mathrm{mg} / \mathrm{mL}$ MOSE before $\mathrm{H}_{2} \mathrm{O}_{2}$ exposure); luteolin $(0.05 \mathrm{mg} / \mathrm{mL})$-treated group (lenses cultured in medium with $0.05 \mathrm{mg} / \mathrm{mL}$ luteolin before $\mathrm{H}_{2} \mathrm{O}_{2}$ exposure).

The lenses were incubated in the medium for $24 \mathrm{~h}$ and then treated with or without $1 \mathrm{mM} \mathrm{H}_{2} \mathrm{O}_{2}$ for $24 \mathrm{~h}$, followed by incubation in fresh medium for another 48 $h$. At the end of the experiments, each lens was examined under the anatomical microscope for morphological changes and then removed from the culture dish, carefully blotted on wet filter paper, weighed, and then immediately frozen for subsequent analysis.

\section{Measurement of lens opacification}

The opacity of lens in each group ( $n=6$ per group) was examined under the anatomical microscope equipped with a charge-coupled device camera. The mean gray value of each lens was measured according to a previous report [36] using ImageJ software (Wayne Rasband National Institutes of Health, USA). The results were expressed as the fold change of the average gray value of the lens from that in the normal control group.

\section{Assessment of ROS generation in lenses}

Direct evidence of intracellular oxidation was observed in lens homogenates using the oxidant sensitive probe DCFH-DA, according to the method of other's reports [37-40] with a slight modification. The DCFH-DA fluorescent probe is oxidized by ROS to produce DCF that is highly fluorescent at $530 \mathrm{~nm}$. At the end of the experiments, the lenses ( $n=6$ per group) were homogenized in a glass homogenizer with $0.9 \%$ saline at a ratio of $1: 9$. To measure ROS generation, the homogenates $(100 \mu \mathrm{L})$ of each sample were mixed with $100 \mu \mathrm{L}$ DCFH-DA $(20 \mu \mathrm{M})$ in a 96-well microplate, and then incubated at $37^{\circ} \mathrm{C}$ in the dark for $30 \mathrm{~min}$. The homogenates were centrifuged at $3000 \times g$ for $15 \mathrm{~min}$ at $4{ }^{\circ} \mathrm{C}$, and the fluorescence of the supernatants was measured using a spectrofluorometer $(488 \mathrm{~nm}$ excitation and $520 \mathrm{~nm}$ emission; Varioskan, Thermo, USA). The result was calculated as the fluorescence intensity per $\mathrm{mg}$ of protein and 
expressed as the fold change of fluorescence intensity from the normal control group.

\section{Assays of GSH content and activities of anti-oxidative enzymes (SOD and CAT) in lens}

After experiments, the lenses were washed with cold $0.9 \%$ saline, dried with filter paper, and weighed. Then, the lenses ( $n=6$ per group) were homogenized in a glass homogenizer with $0.9 \%$ saline at a ratio of $1: 9$. The homogenates were centrifuged at $3000 \times g$ for $15 \mathrm{~min}$ at $4{ }^{\circ} \mathrm{C}$, and the supernatants were collected for assays. GSH content and total SOD and CAT activities were measured using specific assay kits (Nanjing Jiancheng Bioengineering Institute, Nanjing, China), according to the manufacturer's instructions. The protein content of the supernatant was determined using a BCA kit (Applygen Technologies Inc., Beijing, China). For all assays, the activity was calculated as the fold change from the control.

\section{Western blot analysis}

At the end of experiments, the lenses ( $n=3$ per group) were washed with PBS and lysed in RIPA buffer containing protease inhibitors (Aidlab Biotechnologies, Beijing, China) for $30 \mathrm{~min}$ on ice. The lens lysates were centrifuged at $12,000 \times g$ for $20 \mathrm{~min}$ at $4{ }^{\circ} \mathrm{C}$, and the proteins were quantified using the BCA kit. Protein samples $(80 \mu \mathrm{g})$ were separated by $10 \%$ sodium dodecylsulfatepolyacrylamide gel electrophoresis and transferred to polyvinylidene fluoride membranes (Millipore, Billerica MA, USA). The membranes were blocked with $5 \%$ fatfree dry milk for $2 \mathrm{~h}$ and then incubated with a rabbit polyclonal antibody against SOD (1:300, R\&D Systems, Minneapolis, MN, USA), CAT (1:300, Abcam, Cambridge, MA, USA), peroxisome proliferator-activated receptor alpha (PPAR $\alpha)$ (1:500, Abcam, Cambridge, MA, USA), or GAPDH (1:1000, R\&D Systems MN, USA) at $4{ }^{\circ} \mathrm{C}$ overnight. Then, the membranes were incubated with horseradish peroxidase-conjugated anti-rabbit IgG
(1:1000, Cell Signaling Technology Inc., USA) for $2 \mathrm{~h}$. Finally, the protein bands were developed using enhanced chemiluminescence reagents (Millipore). Images were obtained using a Kodak Image Station 4000R (Eastman Kodak Co., Rochester, NY, USA) and analyzed using Kodak Image Software. The optical densities of specific immunopositive bands were normalized to the GAPDH band in the same sample.

\section{Statistical analyses}

Each experiment was performed at least three times. The results are expressed as means \pm standard error of the mean (SEM). Statistical analyses were performed by one-way analysis of variance, followed by Tukey's posthoc test using Prism 5 software for Windows (GraphPad Software Inc., San Diego, CA, USA). Values of $P<0.05$ were considered as statistically significant.

\section{Results}

\section{Total flavonoid content in MOSE}

The total flavonoid content was measured by a NaNO2$\mathrm{Al}(\mathrm{NO} 3) 3-\mathrm{NaOH}$ colorimetric assay. The flavonoid content in MOSE was $169.7 \pm 3.015 \mathrm{mg}$ rutin equivalents $/ \mathrm{g}$ MOSE dry weight, indicating that $1 \mathrm{~g}$ MOSE is equivalent to $169.7 \mathrm{mg}$ rutin.

\section{DPPH-scavenging capacity}

To determine the effect of MOSE and luteolin on radical scavenging, we measured their effects on scavenging DPPH radicals. Both MOSE and luteolin significantly reduced DPPH radicals in a dose-dependent manner $(P<0.05$ vs. control group, Fig. $1 \mathrm{a})$. The $\mathrm{IC}_{50}$ of DPPH radical scavenging was $0.105 \pm 0.0004 \mathrm{mg} / \mathrm{mL}$ for MOSE (Fig. 1a) and $0.014 \pm 0.0007 \mathrm{mg} / \mathrm{mL}$ for luteolin (Fig. 1b). Therefore, the free radical scavenging activity of $1 \mathrm{mg}$ MOSE was approximately equivalent to that of $0.13 \mathrm{mg}$ luteolin.
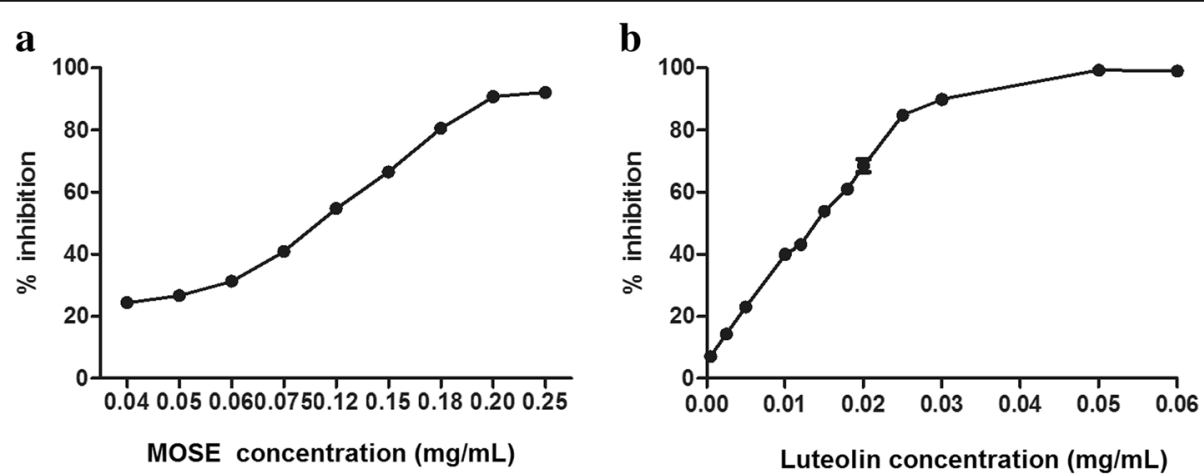

Fig. 1 DPPH radical scavenging assay of MOSE (a) and luteolin (b). The results are expressed as percentage inhibition of DPPH radical formation. Data are expressed as the mean \pm SEM of three separate experiments 
Effects of MOSE and luteolin on lens opacity

To examine the effects of MOSE and luteolin on lens opacity, the change in lens opacity induced by $\mathrm{H}_{2} \mathrm{O}_{2}$ was observed under a stereomicroscope. All lenses in normal control and MOSE pretreatment control groups were transparent, but $1 \mathrm{mM} \mathrm{H}_{2} \mathrm{O}_{2}$ remarkably induced dense cortical vacuolization and opacification (Fig.2 a). After pre-treatment with MOSE $(0.5$ and $1.0 \mathrm{mg} / \mathrm{mL})$, the $\mathrm{H}_{2} \mathrm{O}_{2}$-induced lens opacity levels were reduced remarkably (Fig. 2b). In our preliminary experiment, we found that luteolin as a control also reduced lens opacity, and the effect of luteolin at $0.05 \mathrm{mg} / \mathrm{mL}$ was better than that at $0.1 \mathrm{mg} / \mathrm{mL}$ (Additional file 2: Figure S1). Therefore, 0.05 $\mathrm{mg} / \mathrm{mL}$ luteolin was used in the formal experiments.

\section{Effects of MOSE and luteolin on ROS accumulation, GSH} content, and SOD/CAT activities in lens

To investigate whether MOSE prevents $\mathrm{H}_{2} \mathrm{O}_{2}$-induced ROS generation, ROS levels in lenses were measured using the fluorescent probe DCFH-DA. The basal level of ROS in mouse lens was $16.41 \pm 1.018$ (fluorescence intensity/mg protein), ROS level in lens tissue increased to $50.88 \pm 3.66$ (fluorescence intensity $/ \mathrm{mg}$ protein), about 3 folds to basal level, after exposure to $1 \mathrm{mM}$ $\mathrm{H}_{2} \mathrm{O}_{2}$ for $24 \mathrm{~h}$ (Additional file 1: Table S1 and Fig. 3a), and MOSE $(0.5$ and $1 \mathrm{mg} / \mathrm{mL})$ significantly decreased $\mathrm{H}_{2} \mathrm{O}_{2}$-induced ROS production $(P<0.01$, Fig. 3a). As a control, luteolin also reduced the production of ROS in lenses. There was no obvious difference between MOSE and luteolin for inhibiton of ROS accumulation in lenses (Fig. 3a).

To investigate the mechanisms underlying the antioxidant effect of MOSE, we observed the effect of MOSE on GSH content and the activities of some antioxidant enzymes that participate in ROS degradation. $\mathrm{H}_{2} \mathrm{O}_{2}$ (1 $\mathrm{mM}$ ) markedly decreased GSH content and reduced the activities of SOD and CAT. MOSE (0.5 and $1 \mathrm{mg} / \mathrm{mL})$ significantly increased GSH content and SOD activities in lenses after $\mathrm{H}_{2} \mathrm{O}_{2}$ treatment $(P<0.01$, Fig. 3b, c). Furthermore, MOSE remarkably increased the activity of CAT in lenses by almost 2-fold compared with the control group (Fig. 3d). The effects of MOSE on GSH content and antioxidant enzyme activities were much more potent than those of luteolin in lenses.

\section{Effects of MOSE and luteolin on expressions of SOD, CAT,} and PPARa

To investigate the molecular mechanisms underlying the antioxidant activity of MOSE, protein expression of SOD and CAT was determined. Pre-treatment with MOSE $(1 \mathrm{mg} / \mathrm{mL})$ significantly increased the expression of SOD and CAT $(P<0.01$, Fig. $4 \mathrm{a}, \mathrm{b}, \mathrm{c}$; Additional file 3: Figure S2). Luteolin $(0.05 \mathrm{mg} / \mathrm{mL})$ also increased the expression of SOD, but had no effect on expression of CAT. PPAR $\alpha$ is a ligand-activated transcription factor that plays a key role in modulating the redox balance [41]. Therefore, we examined the effect of MOSE on PPAR $\alpha$ expression in lenses. MOSE $(0.5$ and $1 \mathrm{mg} / \mathrm{mL})$ increased PPAR $\alpha$ expression in lenses after oxidative stress $(\mathrm{P}<0.01$, Fig. 4d; Additional file 3: Figure S2). Luteolin restored the protein expression of PPAR $\alpha$, but did not increase its expression (Fig. 4d).

\section{Discussion}

Oxidative stress plays a major role in cataract formation, and $\mathrm{H}_{2} \mathrm{O}_{2}$ is one of the major oxidants that appears to contribute to cataract formation [42, 43]. In this study, lens organ cultures were used to observe the protective effect of MOSE against lens opacity induced by $\mathrm{H}_{2} \mathrm{O}_{2}$. Although harvesting the lens from the mouse eye without inducing mechanical injury is technically challenging, lens organ culture is a simple and effective method $\mathbf{a}$

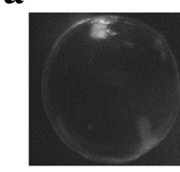

Normal

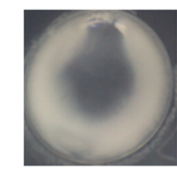

MOSE $0.5 \mathrm{mg} / \mathrm{mL}$ MOSE $1 \mathrm{mg} / \mathrm{mL}$ Luteolin $0.05 \mathrm{mg} / \mathrm{mL}$ b
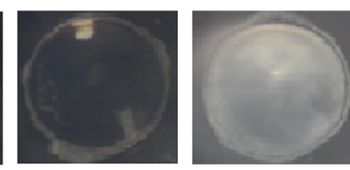

$1 \mathrm{mM} \mathrm{H} \mathrm{H}_{2} \mathrm{O}_{2}$
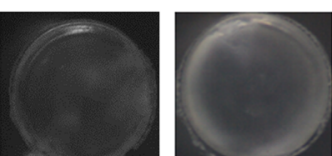

$1 \mathrm{mM} \mathrm{H}_{2} \mathrm{O}_{2}$

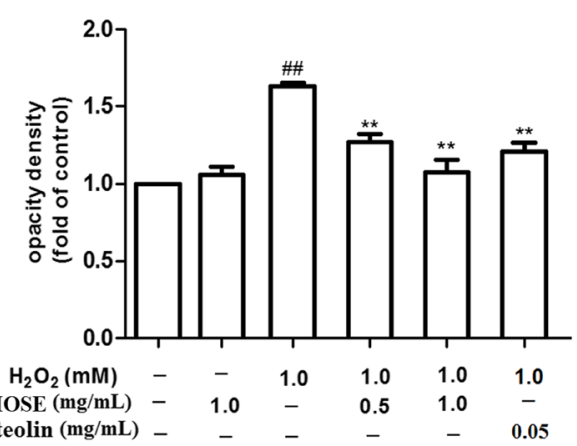

Fig. 2 Effects of MOSE and luteolin on lens opacity in $\mathrm{H}_{2} \mathrm{O}_{2}$-induced cataract. Lenses were pretreated with MOSE (0.5 and $\left.1.0 \mathrm{mg} / \mathrm{mL}\right)$ or luteolin $(0.05$ and $0.1 \mathrm{mg} / \mathrm{mL})$ for $24 \mathrm{~h}$, followed by incubation with $\mathrm{H}_{2} \mathrm{O}_{2}(1 \mathrm{mM})$ for another $24 \mathrm{~h}$ and then recovered in fresh medium for $48 \mathrm{~h}$. a Representative photograph showing the lens with different treatment. $\mathbf{b}$ Quantificaton of lens opacity density. Data are expressed as the mean \pm

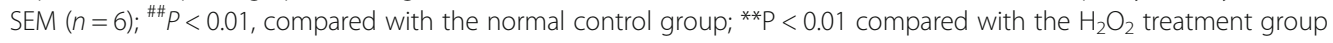



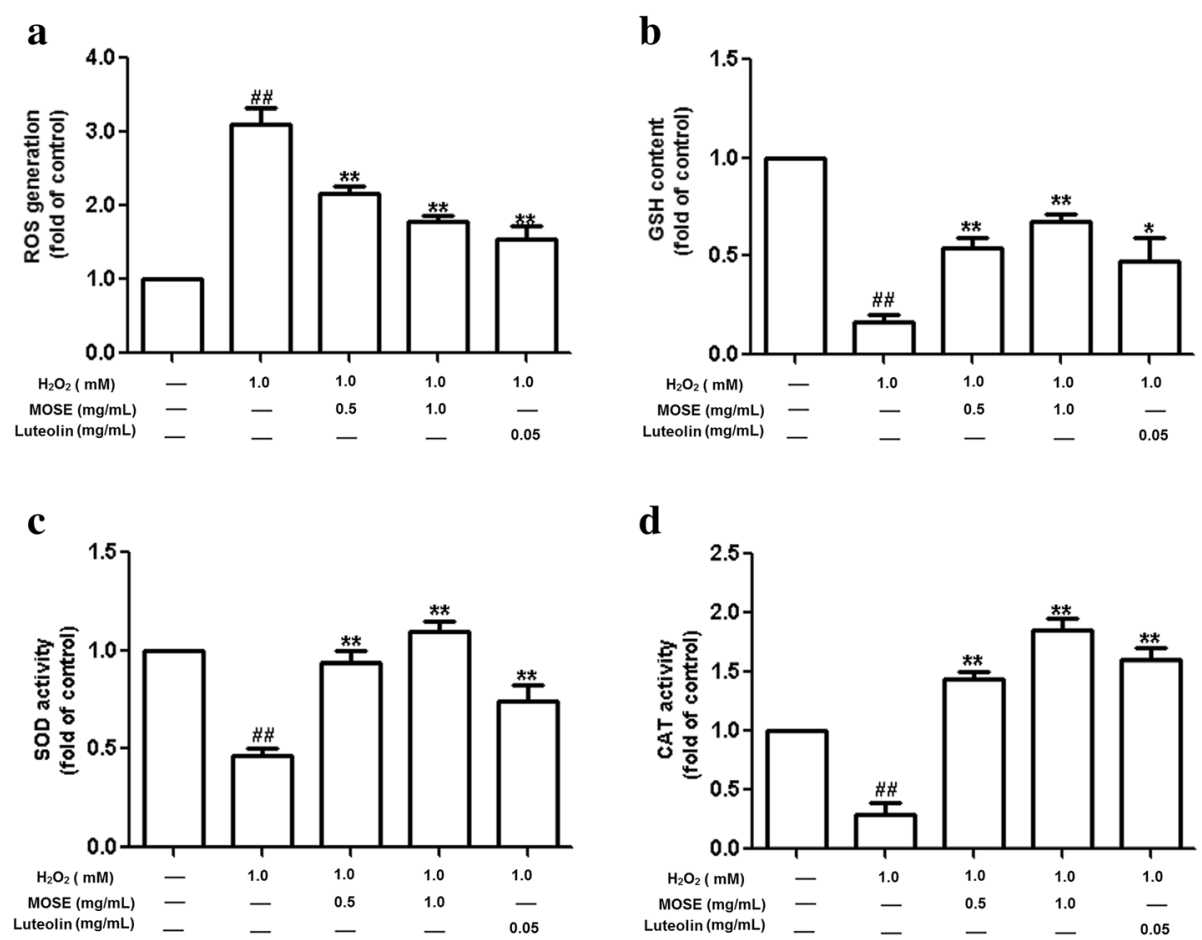

Fig. 3 Effects of MOSE and luteolin on ROS production and SOD, CAT activities in lenses. The fluorescent probe DCFH-DA was used to detect the ROS level in lenses pre-treated with MOSE $(0.5$ and $1.0 \mathrm{mg} / \mathrm{mL})$ or luteolin $(0.05 \mathrm{mg} / \mathrm{mL})$ before $\mathrm{H}_{2} \mathrm{O}_{2}$ exposure. The fluorescent intensities are summarized in a. GSH content (b), and SOD (c) and CAT (d) activities were measured in lenses pretreated with MES or luteolin before $\mathrm{H}_{2} \mathrm{O}_{2}$ exposure. Data are expressed as the mean $\pm \operatorname{SEM}(n=6)$; ${ }^{\# \#} P<0.01$, compared with the normal control group; ${ }^{*} P<0.05$, ${ }^{* *} P<0.01$, compared with the $\mathrm{H}_{2} \mathrm{O}_{2}$ treatment group

to evaluate the effect of candidate compounds on cataract formation $[25,26]$. Our study showed that whole lenses isolated from mouse eyes remained transparent in M-199 medium with 2\% FBS, and all lenses without protection became opaque after exposure to $1 \mathrm{mM} \mathrm{H}_{2} \mathrm{O}_{2}$ for $24 \mathrm{~h}$. MOSE $(0.5$ and $1.0 \mathrm{mg} / \mathrm{mL})$ reduced the opacity of the lens, and $1 \mathrm{mg} / \mathrm{mL}$ MOSE was more effective than $0.5 \mathrm{mg} / \mathrm{mL}$ MOSE. Previous reports indicate that Moringa oliefera has potential inhibitory effects on seleniteinduced cataract in rat pups [21] and high sugar-induced cataract in goat lens in vitro [20]. However, our study shows for the first time that the ethanol extract of Moringa oleifera stem, an agricultural by-product of Moringa oliefera, can also effectively prevent cataract formation induced by $\mathrm{H}_{2} \mathrm{O}_{2}$, a major intracellular ROS, in lens organ culture.

Free radicals are thought to increase the risk of cataract. Our results indicate that MOSE reduces the levels of DPPH free radicals in a cell-free system and inhibits the production of ROS in lenses. However, we also found that, although the effect of luteolin on scavenging free radicals was much better than that of MOSE, the inhibitory effect of MOSE on cataract formation was better than that of luteolin. This result suggests that quenching free radicals directly may not be the main reason for MOSE-mediated inhibition of cataract formation. MOSE may also prevent cataract formation by regulating cellular antioxidant systems. Our study showed that MOSE significantly restored the level of GSH in cultured lenses. There are non-enzymatic and enzymatic endogenous antioxidant systems in human lenses. GSH is an endogenous antioxidant with high content in lenses $[44,45]$. It eliminates superoxide anions, $\mathrm{H}_{2} \mathrm{O}_{2}$, and other oxygen free radicals. In addition, GSH maintains the reduced state of lens proteins, prevents protein denaturation, and plays an important role in the maintenance of lens transparency $[46,47]$.

Furthermore, our study indicates that MOSE upregulates the activities and expressions of SOD and CAT in lenses after $\mathrm{H}_{2} \mathrm{O}_{2}$ exposure. SOD catalyzes the conversion of superoxide anions to $\mathrm{H}_{2} \mathrm{O}_{2}$ plus dioxygen. CAT catalyzes the conversion of $\mathrm{H}_{2} \mathrm{O}_{2}$ to water and oxygen, preventing oxidative damage $[48,49]$. SOD and CAT belong to the antioxidant system that reduces free radicals to less toxic states and play an important role against oxidative stress injury. These results are consistent with another report in which leaf extracts of Moringa oliefera increased the mRNA expression levels of some antioxidant enzymes in HEK-293 cells treated with $\mathrm{H}_{2} \mathrm{O}_{2}$ [15]. As a control, the effects of luteolin on endogenous 
$\mathbf{a}$

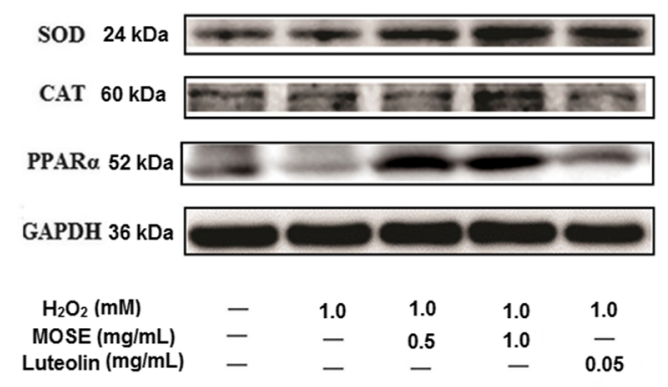

C

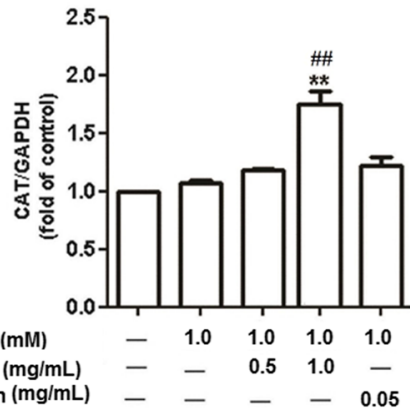

b

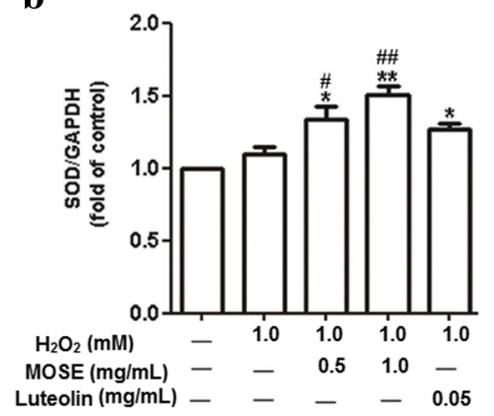

d

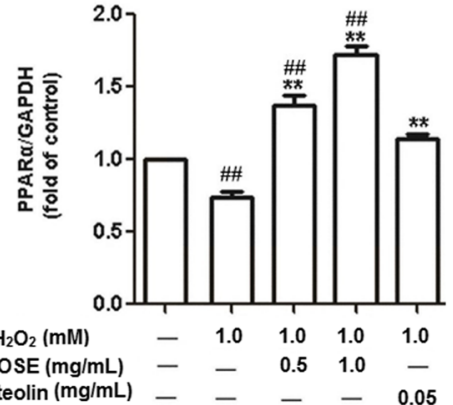

Fig. 4 Effects of MOSE and luteolin on expressions of SOD, CAT and PPARa. Lenses were pretreated with MOSE $(0.5$ and $1.0 \mathrm{mg} / \mathrm{mL}) \mathrm{or} / \mathrm{luteolin}$ $(0.05 \mathrm{mg} / \mathrm{mL})$ for $24 \mathrm{~h}$, followed by incubation with $\mathrm{H}_{2} \mathrm{O}_{2}(1 \mathrm{mM})$ for another $24 \mathrm{~h}$, and then recovered in fresh medium for $48 \mathrm{~h}$. Then, protein expressions were determined by western blot (a). Quantification of western blot for SOD (b), CAT (c), and PPARa (d). Data are expressed as the mean $\pm \operatorname{SEM}(n=3) ;{ }^{\#} \mathrm{P}<0.05$ and ${ }^{\# \#} \mathrm{P}<0.01$, compared with the normal control group; ${ }^{*} \mathrm{P}<0.05$ and ${ }^{* *} \mathrm{P}<0.01$, compared with the $\mathrm{H}_{2} \mathrm{O}_{2}$ treatment group

antioxidant defense were not as potent as those of MOSE. A possible mechanism may be that Moringa oleifera contains more types of antioxidant compounds, such as ascorbic acid, flavonoids, phenolics, and carotenoids [12], which may confer more potent protection by activating the cellular antioxidant system, thereby providing better protection. Therefore, it appears that MOSE may be a more attractive agent to prevent cataract formation.

Another interesting finding of our study was that MOSE markedly increased PPAR $\alpha$ expression at the two doses applied to lenses after oxidative stress. PPARs have been reported to improve or prevent various eye diseases [22-24]. Our study also indicated that lenses with high PPAR $\alpha$ expression retained transparency after oxidative stress, and that MOSE upregulated PPAR $\alpha$ expression in lenses. These results are in line with another report showing that an extract of Moringa oleifera seed increased PPAR $\alpha$ expression in cardiac tissue and exerted protective effects [50]. Genomic and biochemical analyses suggest that oxidative stress might play a significant role in the toxic effects of PPAR $\delta$ or PPAR $\gamma$ agonists on lenses [26]. In contrast, PPAR $\alpha$ has been regarded to play a key role in modulating the redox balance $[41,51$, 52]. PPAR $\alpha$ acts as a transcription factor for diverse target genes possessing a PPAR response element (PPRE) in their promoter region. The PPRE, the binding site for PPAR $\alpha$, has been identified in the promoter regions of genes encoding SOD [53] and CAT [54]. Therefore, SOD and CAT are regarded as target enzymes of PPAR $\alpha$. In fact, many total extracts of natural plants, such as the stems of Cucurbita moschata and leaves of Camellia sinensis, have been reported to modulate PPAR $\alpha$ activity [55]. Collectively, these results indicate that PPAR $\alpha$ may be involved in the inhibitory effect of MOSE on cataract formation induced by oxidative stress. However, the detailed role of PPAR $\alpha$ in the lens requires further investigation. In addition, we only examined the effect of the crude extract of Moringa oleifera stem in this study, and specific phytochemicals in MOSE have not been comprehensively evaluated. Further studies are required to identify the active flavonoids in the fraction responsible for the anti-cataract formation effect and PPAR $\alpha$ activating effect in the future.

\section{Conclusion}

In summary, the results of this study show that MOSE significantly delays the progression of $\mathrm{H}_{2} \mathrm{O}_{2}$-induced cataract formation in lens organ culture, and the mechanisms underlying its effect are related to scavenging of 
free radicals, increasing GSH content, and enhanced activities and expressions of SOD, CAT, and PPAR $\alpha$. Moringa oleifera stem, as a kind of natural antioxidant, has extensive sources and no obvious adverse effects. Therefore, the inhibitory effect of MOSE on cataract formation has great clinical interest. It can be used as a potential natural medicine in the prevention or treatment of cataract, especially induced by diabetes.

\section{Additional files}

Additional file 1: Table S1. Quantitative analysis of ROS in lens(fluorescence intensity/mg protein, means \pm SEM, $n=6$. (DOCX $19 \mathrm{~kb}$ )

Additional file 2: Figure S1. Effects of luteolin on lens opacity in $\mathrm{H}_{2} \mathrm{O}_{2}$ induced cataract. Lenses were pretreated with luteolin $(0.01,0.05$ and 0.1 $\mathrm{mg} / \mathrm{mL}$ ) for $24 \mathrm{~h}$, followed by incubation with $\mathrm{H}_{2} \mathrm{O}_{2}(1 \mathrm{mM})$ for another $24 \mathrm{~h}$ and then recovered in fresh medium for $48 \mathrm{~h}$. Data are expressed as the mean \pm SEM $(n=6)$; \#\#P<0.01, compared with the normal control group; ${ }^{*} \mathrm{P}<0.01$ compared with the $\mathrm{H}_{2} \mathrm{O}_{2}$ treatment group. (TIF $584 \mathrm{~kb}$ )

Additional file 3: Figure S2. The original gel images of Fig. 4a. (TIF 155 kb)

\section{Abbreviations}

CAT: Catalase; DCFH-DA: 2', 7'-Dichlorofluorescein diacetate; DPPH: 2,2Diphenyl-1-1-picrylhydrazyl; FBS: Fetal bovine serum; GSH: Reduced glutathione; $\mathrm{H}_{2} \mathrm{O}_{2}$ : Hydrogen peroxide; M-199: Medium 199; MOSE: Moringa oleifera stem extract; PPARa: Proliferator-activated receptor alpha; RIPA: Radioimmunoprecipitation assay; ROS: Reactive oxygen species; SOD: Superoxide dismutase

\section{Acknowledgements}

The authors thank Wenliang Deng (Information \& Network Services of Xiamen University) for his computer technical assistance.

\section{Authors' contributions}

$X J$ and $Y L$ were responsible for the conception and design of this study. $L Q$, WJL and MLZ acquired the data. LQ analyzed and interpreted the data, and drafted the manuscript. YZ revised the manuscript and did the final approval of the manuscript. All authors read and approved the final version of the manuscript.

\section{Funding}

This work was supported by the Special Funds for the Science and Technology Program of Traditional Chinese Medicine from Fujian Provincial Department of Health (Grant No.wzhw201302), the Special Funds for the Science and Technology Program of Public Wellbeing from Xiamen Science and Technology Bureau (Grant No.3502Z20144030), the Medical Innovation Project of Fujian, China(Grant No.2015-CXB-43)and the Special Funds from the Xiamen Chuanming Biological Technology Co. Ltd. (Grant No.XDHT2015241A)

\section{Availability of data and materials}

All data generated or analyzed during this study are included in this published article. More details are available from the corresponding author on reasonable request.

\section{Ethics approval and consent to participate}

All experimental protocols described in the present study were approved by the Animal Care and Use Committee of Xiamen University (LACUC: XMULAC20150077). All procedures for the animal study were conducted in accordance with ARRIVE guidelines, and every effort was made to alleviate the suffering of the animals.

\section{Consent for publication}

Not applicable.

\section{Competing interests}

The authors declare that they have no competing interests.

\section{Author details}

${ }^{1}$ Department of Ophthalmology, Xiamen Hospital of Traditional Chinese Medicine, Xiamen 361005, People's Republic of China. ${ }^{2}$ Department of Basic Medical Science, School of Medicine, Xiamen University, Xiamen 361102, People's Republic of China.

Received: 8 August 2018 Accepted: 10 June 2019

Published online: 21 June 2019

\section{References}

1. Lee CM, Afshari NA. The global state of cataract blindness. Curr Opin Ophthalmol. 2017;28(1):98-103.

2. Fukuoka $\mathrm{H}$, Afshari NA. The impact of age-related cataract on measures of frailty in an aging global population. Curr Opin Ophthalmol. 2017;28(1):93-7.

3. Lofgren S. Solar ultraviolet radiation cataract. Exp Eye Res. 2016.

4. Smith AJ, Ball SS, Manzar K, Bowater RP, Wormstone IM. Ku80 counters oxidative stress-induced DNA damage and cataract formation in the human Lens. Invest Ophthalmol Vis Sci. 2015;56(13):7868-74.

5. Kruk J, Kubasik-Kladna K, Aboul-Enein HY. The role oxidative stress in the pathogenesis of eye diseases: current status and a dual role of physical activity. Mini Rev Med Chem. 2015;16(3):241-57.

6. Ji Y, Cai L, Zheng T, Ye H, Rong X, Rao J, Lu Y. The mechanism of UVB irradiation induced-apoptosis in cataract. Mol Cell Biochem. 2015;401(1-2): 87-95.

7. Sunkireddy P, Jha SN, Kanwar JR, Yadav SC. Natural antioxidant biomolecules promises future nanomedicine based therapy for cataract. Colloids Surf B Biointerfaces. 2013;112:554-62.

8. Dubey S, Saha S, Kaithwas G, Saraf SA. Effect of standardized fruit extract of Luffa cylindrica on oxidative stress markers in hydrogen peroxide induced cataract. Indian J Pharmacol. 2015;47(6):644-8.

9. Varma SD, Hegde KR. Kynurenine-induced photo oxidative damage to lens in vitro: protective effect of caffeine. Mol Cell Biochem. 2010;340(1-2):49-54.

10. Grover AK, Samson SE. Antioxidants and vision health: facts and fiction. Mol Cell Biochem. 2014;388(1-2):173-83.

11. Kou X, Li B, Olayanju JB, Drake JM, Chen N. Nutraceutical or pharmacological potential of Moringa oleifera lam. Nutrients. 2018;10(3).

12. Saini RK, Sivanesan I, Keum YS: Phytochemicals of Moringa oleifera: a review of their nutritional, therapeutic and industrial significance. 3 Biotech. 2016; 6(2):203.

13. Stohs SJ, Hartman MJ. Review of the safety and efficacy of Moringa oleifera. Phytother Res. 2015:29(6):796-804.

14. Sreelatha S, Padma PR. Modulatory effects of Moringa oleifera extracts against hydrogen peroxide-induced cytotoxicity and oxidative damage. Hum Exp Toxicol. 2011;30(9):1359-68.

15. Vongsak B, Mangmool S, Gritsanapan W. Antioxidant activity and induction of mRNA expressions of antioxidant enzymes in HEK-293 cells of Moringa oleifera leaf extract. Planta Med. 2015;81(12-13):1084-9.

16. Kerdsomboon K, Tatip S, Kosasih S, Auesukaree C. Soluble Moringa oleifera leaf extract reduces intracellular cadmium accumulation and oxidative stress in Saccharomyces cerevisiae. J Biosci Bioeng. 2016;121(5):543-9.

17. Jaiswal D, Rai PK, Mehta S, Chatterii S, Shukla S, Rai DK, Sharma G, Sharma B, Khair S, Watal G. Role of Moringa oleifera in regulation of diabetes-induced oxidative stress. Asian Pac J Trop Med. 2013;6(6):426-32.

18. Das N, Ganguli D, Dey S. Moringa oleifera lam. Seed extract prevents fat diet induced oxidative stress in mice and protects liver cell-nuclei from hydroxyl radical mediated damage. Indian J Exp Biol. 2015:53(12):794-802.

19. Agrawal ND, Nirala SK, Shukla S, Mathur R. Co-administration of adjuvants along with Moringa oleifera attenuates beryllium-induced oxidative stress and histopathological alterations in rats. Pharm Biol. 2015;53(10):1465-73.

20. Kurmi R, Ganeshpurkar A, Bansal D, Agnihotri A, Dubey N. Ethanol extract of Moringa oliefera prevents in vitro glucose induced cataract on isolated goat eye lens. Indian J Ophthalmol. 2014;62(2):154-7.

21. Sasikala V, Rooban BN, Priya SG, Sahasranamam V, Abraham A. Moringa oleifera prevents selenite-induced cataractogenesis in rat pups. J Ocul Pharmacol Ther. 2010;26(5):441-7.

22. Moran E, Ding L, Wang Z, Cheng R, Chen Q, Moore R, Takahashi Y, Ma JX. Protective and antioxidant effects of PPARalpha in the ischemic retina. Invest Ophthalmol Vis Sci. 2014;55(7):4568-76. 
23. Khatol P, Saraf $S$, Jain A. Peroxisome proliferated activated receptors (PPARs): opportunities and challenges for ocular therapy. Crit Rev Ther Drug Carrier Syst. 2018;35(1):65-97.

24. Chen Q, Qiu F, Zhou K, Matlock HG, Takahashi Y, Rajala RVS, Yang Y, Moran E, Ma JX. Pathogenic role of microRNA-21 in diabetic retinopathy through downregulation of PPARalpha. Diabetes. 2017;66(6):1671-82.

25. Qi HP, Wei SQ, Zhang LQ, Gao XC, Yu NN, Bi S, Cui H. Preventive effect of danshensu on selenite-induced cataractogenesis in cultured rat lens. Clin Exp Ophthalmol. 2013;41(2):172-9.

26. Sampath S, McLean LA, Buono C, Moulin P, Wolf A, Chibout SD, Pognan F, Busch S, Shangari N, Cruz E, et al. The use of rat lens explant cultures to study the mechanism of drug-induced cataractogenesis. Toxicol Sci. 2012; 126(1):128-39.

27. Basu S, Rajakaruna S, Dickinson BC, Chang CJ, Menko AS. Endogenous hydrogen peroxide production in the epithelium of the developing embryonic lens. Mol Vis. 2014;20:458-67.

28. Cornish KM, Williamson G, Sanderson J. Quercetin metabolism in the lens: role in inhibition of hydrogen peroxide induced cataract. Free Radic Biol Med. 2002;33(1):63-70

29. Sreelakshmi V, Sasikala V, Abraham A. Luteolin supplementation prevents selenite-induced Cataractogenesis in Spraque Dawley rat pups. Chem Biodivers. 2015;12(12):1881-90.

30. Rooban BN, Sasikala V, Gayathri Devi V, Sahasranamam V, Abraham A. Prevention of selenite induced oxidative stress and cataractogenesis by luteolin isolated from Vitex negundo. Chem Biol Interact. 2012;196(1-2):30-8.

31. Chen $Y$, Sun XB, Lu HE, Wang F, Fan XH. Effect of luteoin in delaying cataract in STZ-induced diabetic rats. Arch Pharm Res. 2017:40(1):88-95.

32. Bao YF, Li JY, Zheng LF, Li HY. Antioxidant activities of cold-nature Tibetan herbs are signifcantly greater than hot-nature ones and are associated with their levels of total phenolic components. Chin J Nat Med. 2015;13(8):609-17.

33. Yamaguchi T, Takamura H, Matoba T, Terao J. HPLC method for evaluation of the free radical-scavenging activity of foods by using 1,1-diphenyl-2picrylhydrazyl. Biosci Biotechnol Biochem. 1998;62(6):1201-4.

34. Devi VG, Rooban BN, Sasikala V, Sahasranamam V, Abraham A Isorhamnetin-3-glucoside alleviates oxidative stress and opacification in selenite cataract in vitro. Toxicol in Vitro. 2010:24(6):1662-9.

35. Biju PG, Rooban BN, Lija Y, Devi VG, Sahasranamam V, Abraham A. Drevogenin D prevents selenite-induced oxidative stress and calpain activation in cultured rat lens. Mol Vis. 2007;13:1121-9.

36. Lu Q, Yang T, Zhang M, Du L, Liu L, Zhang N, Guo H, Zhang F, Hu G, Yin X. Preventative effects of Ginkgo biloba extract (EGb761) on high glucosecultured opacity of rat lens. Phytother Res. 2014;28(5):767-73.

37. Shukla R, Banerjee S, Tripathi YB. Antioxidant and Antiapoptotic effect of aqueous extract of Pueraria tuberosa (Roxb. Ex Willd.) DC. On streptozotocin-induced diabetic nephropathy in rats. BMC Complement Altern Med. 2018;18(1):156

38. Asha R, Gayathri Devi V, Abraham A. Lupeol, a pentacyclic triterpenoid isolated from Vernonia cinerea attenuate selenite induced cataract formation in Sprague Dawley rat pups. Chem Biol Interact. 2016;245:20-9.

39. Rooban BN, Sasikala V, Sahasranamam V, Abraham A. Amelioration of selenite toxicity and cataractogenesis in cultured rat lenses by Vitex negundo. Graefes Arch Clin Exp Ophthalmol. 2011;249(5):685-92.

40. Kim MS, Lee DY, Lee J, Kim HW, Sung SH, Han JS, Jeon WK. Terminalia chebula extract prevents scopolamine-induced amnesia via cholinergic modulation and anti-oxidative effects in mice. BMC Complement Altern Med. 2018;18(1):136.

41. Aleshin $\mathrm{S}$, Reiser $\mathrm{G}$. Role of the peroxisome proliferator-activated receptors (PPAR)-alpha, beta/delta and gamma triad in regulation of reactive oxygen species signaling in brain. Biol Chem. 2013;394(12):1553-70.

42. Gao S, Qin T, Liu Z, Caceres MA, Ronchi CF, Chen CY, Yeum KJ, Taylor A, Blumberg JB, Liu Y, et al. Lutein and zeaxanthin supplementation reduces $\mathrm{H}_{2} \mathrm{O}_{2}$-induced oxidative damage in human lens epithelial cells. Mol Vis. 2011;17:3180-90.

43. Smith AJ, Ball SS, Bowater RP, Wormstone IM. PARP-1 inhibition influences the oxidative stress response of the human lens. Redox Biol. 2016;8:354-62.

44. Harding JJ. Free and protein-bound glutathione in normal and cataractous human lenses. Biochem J. 1970;117(5):957-60.

45. Nye-Wood MG, Spraggins JM, Caprioli RM, Schey KL, Donaldson PJ, Grey AC. Spatial distributions of glutathione and its endogenous conjugates in normal bovine lens and a model of lens aging. Exp Eye Res. 2017;154:70-8.

46. Giblin FJ. Glutathione: a vital lens antioxidant. J Ocul Pharmacol Ther. 2000; 16(2):121-35.
47. Sweeney MH, Truscott RJ. An impediment to glutathione diffusion in older normal human lenses: a possible precondition for nuclear cataract. Exp Eye Res. 1998;67(5):587-95.

48. Reczek CR, Chandel NS. ROS-dependent signal transduction. Curr Opin Cell Biol. 2015;33:8-13.

49. Schieber $M$, Chandel NS. ROS function in redox signaling and oxidative stress. Curr Biol. 2014;24(10):R453-62.

50. Randriamboavonjy Jl, Loirand G, Vaillant N, Lauzier B, Derbre S, Michalet S, Pacaud P, Tesse A. Cardiac protective effects of Moringa oleifera seeds in spontaneous hypertensive rats. Am J Hypertens. 2016;29(7):873-81.

51. Manea A, Manea SA, Todirita A, Albulescu IC, Raicu M, Sasson S, Simionescu M. High-glucose-increased expression and activation of NADPH oxidase in human vascular smooth muscle cells is mediated by 4-hydroxynonenalactivated PPARalpha and PPARbeta/delta. Cell Tissue Res. 2015;361(2):593604.

52. Abdelmegeed MA, Moon KH, Hardwick JP, Gonzalez FJ, Song BJ. Role of peroxisome proliferator-activated receptor-alpha in fasting-mediated oxidative stress. Free Radic Biol Med. 2009;47(6):767-78.

53. Yoo HY, Chang MS, Rho HM. Induction of the rat $\mathrm{cu} / \mathrm{Zn}$ superoxide dismutase gene through the peroxisome proliferator-responsive element by arachidonic acid. Gene. 1999;234(1):87-91.

54. Girnun GD, Domann FE, Moore SA, Robbins ME. Identification of a functional peroxisome proliferator-activated receptor response element in the rat catalase promoter. Mol Endocrinol. 2002;16(12):2793-801.

55. Rigano D, Sirignano C, Taglialatela-Scafati O. The potential of natural products for targeting PPARalpha. Acta Pharm Sin B. 2017:7(4):427-38.

\section{Publisher's Note}

Springer Nature remains neutral with regard to jurisdictional claims in published maps and institutional affiliations.

Ready to submit your research? Choose BMC and benefit from:

- fast, convenient online submission

- thorough peer review by experienced researchers in your field

- rapid publication on acceptance

- support for research data, including large and complex data types

- gold Open Access which fosters wider collaboration and increased citations

- maximum visibility for your research: over $100 \mathrm{M}$ website views per year

At BMC, research is always in progress.

Learn more biomedcentral.com/submissions 